УДК 947(470.6)

\title{
КАВКАЗ НАЧАЛА ХІХ В. В ПУТЕВЫХ ЗАМЕТКАХ ДЖОНА ДЖОНСОНА
}

Статья посвящена решению важной в кавказоведении задаче - введению в научный оборот новых источников для изучения широкого круга региональных аспектов. При том, что современное кавказоведение располагает обширной базой записей российских путешественников по региону, иностранных источников в ней представлено мало. Особенно это касается первой половины XIX в., источников, созданных до возникновения российско-британского противостояния на Кавказе.

Автор анализирует ранее не переводившиеся на русский язык дневниковые записки офицера Британской армии Джона Джонсона, совершившего в 1817 г. поездку по региону во время его путешествия из Индии в Англию. В статье приводятся не только отдельные детали условий жизни людей на южном приграничье, но и оценки очевидцем российской военно-гражданской администрации. Это - описание посольства А. П. Ермолова в Персии, российских городов и поселений в регио- не, природы и жителей Горного Кавказа, способов путешествия и системы организации карантинной службы. Особое внимание уделено аналитической части записок - оценке Британским военным позитивных действий России и ее армии на Кавказе, направленных на интеграцию территорий в состав единой империи. Российский стиль управления и инкорпорация местных элит выступает у Джонсона аргументом для критики системы открытого колониального грабежа, практиковавшегося в первой половине XIX в. Ост-Индской кампанией В конце статьи, делается вывод об общих особенностях заметок европейцев о Востоке и значимости их использования как первоисточника.

Ключевые слова: Записки иностранцев о Кавказе города и поселения на Кавказе, А. П. Ермолов, российская военно-гражданская администрация, инкорпорация элит, кавказская одежда, путешествия, Дарьяльское ущелье, почтовая служба, карантины.

D. S. Tkachenko

\section{THE EARLY XIX c. CAUCASUS IN THE VOYAGE ACCOUNTS OF JOHN JOHNSON}

The paper focuses on solving a very important challenge setting an access to new primary sources on vague regional issues for Russian-speakers. Although the modern Caucasus studies in Russia have a long list of accounts related to Russian authors there seems to be a lack of foreign-based sources. It particularly concerns the early XIX c. - the sources that covered the experience of people before the Russian-British rivalry on the Caucasus.

The author scrutinises the diary entries of the British Lieutenant Colonel John Johnson who took off India for Britain in 1817 and made his way trough the Middle East and Caucasus. He put the experience in the diary that had been never translated into Russian. The article focuses on his descriptions of the South frontier routine together with Johnson's conclusions concerning the Caucasus military and civil authorities. The entries include some additional information about the Yermolov's Embassy to Persia, Rus-

Обращение к тематике заметок иностранцев как в целом о России, так и о кавказском регионе имеет высокий научный потенциал. Записи иностранцев, прежде всего интересны тем, что человек, принадлежащий к иной социокультурной реальности, часто подмечал такие детали жизненного, политического и культурного уклада, которые, будучи привычными, не вызывали интереса у соотечественника и оставались вне сферы русскоязычных источников. В аналитической части своих размышлений иностранцы часто sian towns and dwelling places in the region, the beauty of the Mountain Caucasus nature and merits of its inhabitancies. He also described the way of travelling through the Caucasus and the quarantine service. The analytic part of the entries shows the positive experience of Russian militaries in setting up the pattern of the territories acquisition within the Empire together with the absorption of the local elites. The experience is shown as an argument for questioning the way the Ost-India Company used to exploit the Subcontinent. Finally, the author generalises the way we can use the European explores accounts on the Orient as a primary source for our studies.

Key words: foreigners accounts on the Caucasus, the Caucasus towns and dwelling places, A. P. Yermolov, Russian military and civil administration, incorporation of elites, Caucasus dress-style, travelling, theDaryal Gorge, postal service, quarantine service.

проводили параллели с действиями собственных государств, отыскивая как аналогии, так и противопоставления. Эта сторона записок, в свете современного внимания к изучению геополитического соперничества России и Западных стран в реализации Восточной политики, представляет особый интерес.

Записки одного из английских путешественников - подполковника Британской армии Джона Джонсона, побывавшего на Кавказе в конце второго десятилетия XIX В., представляют собой исто- 
рический источник по широкому кругу вопросов, связанных с исследованием Ближнего Востока и Кавказа. Записки выполнены в форме дневниковых записей, в которых путешественник отмечал не только сведения фактического характера, но и фиксировал свои размышления. Судя по тому, что книга Джонсона вышла на следующий год после поездки, сведения, приводимые автором, представляли большой интерес для британской колониальной администрации на Ближнем Востоке. Косвенным подтверждением этого может быть то, что доступная для изучения копия труда, хранящаяся в настоящее время в национальной библиотеке республики Катар, имеет на обложке печать одного из высших государственных органов Британской империи, отвечавшего за проведение Раджа - Secretary of State for India [6].

Содержание записок охватывает материал, собранный путешественниками со времени отъезда из Бомбея до их прибытия в Лондон. Наибольшее время - 5 месяцев, автором было проведено на землях Персии, что показывает явный интерес к изучению сопредельных с Британской Индией территорий. Путь от российско-персидской границы до Лондона был для автора уже не так важен и занял всего 2 месяца - время сопоставимое с тем, которое тратили путешественники, отправляясь на Кавказ из центра Российской империи [1] Наиболее любопытными, на наш взгляд, являются главы XIV и XV, описывающие путь по Закавказью и Кавказской области, а так же частично, материал XII и XVI глав, передающие их впечатления от посещения российского посольства в Персии и пребывание на Дону в гостях у атамана Платова. Текст книги написан красивым, чистым, но несколько архаичным английским языком Автор был наблюдательным, имел четкий склад ума, однако составлял свое издание в расчете на то, что его будут читать соотечественники, а не иностранцы.

Мы можем только гадать, была ли поездка англичанина его личной инициативой, или за ней скрывалась разведывательная миссия - об этом автор заметок, разумеется, умолчал. Однако скрупулезный характер сделанных им зарисовок всех мест, по которым шла дорога, точно согласуется с инструкциями военным разведчикам (как британским, так и российским) о том, какие сведения они должны представлять в рапортах об обследованной территории [3]. Офицер указал точные расстояния между населенными пунктами, отсчитывая время пути с точностью до 15 минут; описал основные ориентиры и достопримечательности местности; от внимания англичанина не ускользнуло состояние дорог - даже то из какого материала они состояли; направление течений рек и ручьев; характер переправ через водные преграды и, конечно, облик местных жителей. Сам характер педантичных записей позволяет читателю сделать вывод, что интерес к ведущим в Индию сухопутным путям у британского офицера был далеко не частным.

Подполковник Джонсон так же был не случайным человеком на этом пути. О себе он вскользь сообщает, что имеет опыт 35-летней службы в Индии, «большая часть которой была посвящена приобретению знаний, как профессионального характера, так и сведений о местных жителях... а связанные с этим обязанности в теченье целых месяцев и даже лет обрекают человека на жизнь среди туземцев без общества единого Европейца» $[7$, р. III], - писал он.

Человек с богатым опытом ведения разведки в полевых условиях, в феврале 1817 г. вместе со своим сослуживцем - капитаном Сатлером, покинул место службы в Британском Бомбее и отправился в метрополию. Объясняя мотивы, заставившие англичан избрать сухопутный путь, автор отмечает, что на выбор повлияла прежде всего, стабилизировавшаяся международная обстановка «глобальный мир, установленный как в Персии, так и на всем Европейском континенте» [7, р. 1], наступивший после завершения Наполеоновских войн. Возросшее могущество Британии, «давало надежду на то, что сама принадлежность к англичанам будет лучшим видом паспорта на всех территориях от Индии до Балтики» [7, р. 1-2]

Отплыв из Бомбея на борту торгового судна, англичане добрались до города Бушер на Юге Ирана. Далее, через персидские владения и курдские земли они двинулись на Северо-Запад в Прикаспийские провинции. Через 3 месяца пути они достигли границ Российского Кавказа.

Знакомство с российской администрацией состоялось у англичан задолго до того, как они вступили в пределы Империи. В Персии пребывало посольство, возглавляемое командующим Отдельным Кавказским корпусом А. П. Ермоловым, который в 1817 г. был направлен к султану Фетх-Али для подтверждения статей Гюлитстанского трактата и для обозрения российско-персидской границы. Последним он и занимался летом 1817 г., судя по тому, что англичане застали посла во временном лагере в Туркманчае, а не в постоянном российском представительстве в Тебризе. Посольство произвело на путешественников очень благоприятное впечатление. «Люди в посольстве происходят из лучших Русских родов и из их разговоров, которые они ведут на Французском, видно, что они очень хорошо образованы. Посольство состоит из генерала, двух консулов, около 30 офицеров, художника, лекаря, топографа, 24 русских солдат-кавалеристов, нескольких казачьих офицеров и черкесов», [7, p. 201] - писал Джонсон.

А. П. Ермолов принял путешественников лично, проявив особое гостеприимство. "Он сам офицер высочайших достоинств, обладает доверием своего государя, служением которому верой и правдой он занимался во время последних войн с Францией. ... Сам генерал имеет восемнадцать разных орденов, среди которых есть три звезды; но так как он носит простое платье, то никогда их не надевает» [7, р. 200], - восторженно отзывался путешественник. А. П. Ермолов несколько раз приглашал иностранцев на обед, обеспечил их палатками, продовольствием и всем необходимым, а перед отъездом, как Командующий корпу- 
сом, снабдил их рекомендательными письмами к администраторам на Кавказе. Письма очень помогли путешественникам в дальнейшем. Генерал так же просил англичан передать по пути корреспонденцию своим подчиненным, друзьям и знакомым, начиная от офицера, командовавшего первым российским приграничным постом с Персией и заканчивая письмами атаману Платову в Новочеркасск и Великому князю Константину в Варшаву [7, р. 206]. В свою очередь, представителей русского посольства интересовал маршрут, которым английские офицеры следовали на Кавказ из места их службы, и генерал лично расспрашивал о нем в течение целого дня [7, p. 206]. Несмотря на то, что англичане в своих записках не придавали вопросам русских офицеров особого значения, отметим, что поисками путей в Индию через земли Ближнего Востока занимались многие российские администраторы и до, и после А. П. Ермолова [4].

Самих же путешественников обходительность генерала просто пленила. В заметках о времени, проведенном с командующим Кавказским корпусом, Д. Джонсон приводит яркую деталь. Узнав, что среди свиты генерала есть представители кавказских народов, любопытные англичане стали просить показать им «черкеса». А. П. Ермолов выполнил просьбу: одного «черкеса» нарядили в военный костюм латника, и он выехал к англичанам верхом на коне, а второй оделся в повседневную одежду кавказского горца. «Генерал Ермолов, предвидя, что я буду крайне изумлен и захочу иметь их рисунок, распорядился, чтобы художник из посольства сделал два рисунка этих людей на листе, который он мне и отдал» $[7$, р. 207], - пишет Д. Джонсон. Жители Кавказа, таким образом, представлялись путешественникам достойными особого любопытства со стороны представителей цивилизованных народов.

Вместе с тем, взгляд англичанина содержит не только явный европоцентризм, но и точную оценку позитивных действий российских властей в регионе. «Русское правительство, - пишет Д. Джонсон, - приобретая любое новое владение, например, такое, как Грузия, фрормирующее с этого времени часть империи, очень старается не оттолкнуть от себя влиятельных людей, которые раньше были наделены властью или занимали какое-то важное положение. Они не смещают существующих должностных лиц для того, чтобы передать их посты русским ... фаворитам из числа придворных; напротив, они всех их, ... оставляют на своих местах, за очень небольшим исключением ... ; тем самым они скорее стимулируют, чем отторгают амбиции и будущее служебное рвение местных жителей. Фактически, им предлагается защита и открывается гораздо более обширная и привлекательная цель для приложения усилий, расширяются горизонты и возникают блестящие перспективы под правлением гораздо более могущественного правительства, чем то, чьи интересы они ранее представляли. С помощью таких мягких и осторожных действий, приобретение новой территории осуществляется с минималь- ным уроном для чувств населяющих ее людей, большинство из которых, не видя какого-то существенного изменения привычного порядка вещей, крайне мало волнуется тем, что произошла передача верховной власти» [7, p. 202]. Британский офицер видит в этом явный позитив по сравнению с методами действий Ост-Индской кампании в Индии. Ее администраторы, по словам Джонса, приобретая новые территории, прежде всего заботятся о том, «чтобы обеспечить материальный доход и продвижение по службе лицам, занимающим вершину списка. Тем самым становится необходимым для лиц туземного происхождения скорее развенчать, чем укрепить их надежды на увеличение влияния, которое они бы могли получить от своего текущего политического или экономического положения после поглощения их территории» [7, р. 202].

Еще более точные представления о реалиях жизни на Российском Кавказе путники получили, перейдя границу у Караклиса на 16-м дне пути от лагеря под Туркманчаем. На пограничном посту им поменяли часть денег по установленному курсу. Рубль автор считает «чем-то, напоминающим доллар» [7, р. 237] и удивляется российской практике различать по покупательной способности серебряные рубли и ассигнации. Несмотря на единый номинал рубля, «за один серебряный дают четыре бумажных» [7, p. 237], - пишет англичанин.

Русская почтовая служба вызвала у путешественников большое уважение. Д. Джонсон пишет, что благодаря письмам генерала Ермолова, англичане получили возможность воспользоваться почтовыми станциями, которые русские завели сразу же от границы с Персией. Путь до Тифлиса занял у них всего 3 дня. Однако, за удобство передвиженья иностранцам пришлось платить. «Русская мера расстоянья - верста, эквивалентна примерно 2/3 мили. Плата за каждую версту 2 копейки серебром. На каждой станции мы находили хлеб, домашнюю птицу и яйца, которые казаки с большой любезностью готовили для нас» $[7$, p. 239], описывает он свой путь по Закавказью.

При этом автор отмечает, что главную роль в поддержании сообщения в Закавказье играли казаки, несущие транспортную повинность. «Говоря об этом роде войск, я без преувеличенья скажу, что они являются самым полезным для условий этой страны. Как солдаты, так и офицеры не проявляют особой требовательности к условиям квартирования: почтовая станция, на которой мь сейчас находимся, несомненно, имеет условия, которые удовлетворили бы лишь нашего сержанта, а распоряжается ей офицер в чине майора. Этот человек очень расторопно и энергично погрузил наш багаж на лошадей, в течение всего пути был очень внимателен, стремясь выполнить не только наши нужды, но и прихоти» $[7$, р. 240]. Вскоре англичане прибыли в Тифлис, где были встречены генерал-губернатором А. П. Кутузовым, который во время отсутствия командующего корпусом управлял на Кавказе всей военной и гражданской частью. 
Генерал Кутузов оказал путешественникам теплый прием: прочитав рекомендательные письма А. П. Ермолова, он пригласил англичан на обед и лично проводил их по Тифлису, указывая достопримечательности города. Однако, столица Российского Кавказа не произвела на англичан особого впечатления. «Я редко встречал столь безынтересную городскую застройку» [7, р. 242], прокомментировал Д. Джонсон свои впечатления. Тем не менее, путешественники отметили появление в Тифлисе явных европейских черт, таких как «введение регулировки движения по улицам приведение в порядок фасадов домов и возведение новых зданий» [7, р. 246-247].

Англичане так же прошли и официальную процедуру проверки. «Дпя въезда в Грузию требуется паспорт, который выдает британский консул в Персии: в Тифлисе этот документ проверяется и для путешествия по России выдается другой. Если путник не хочет, чтобы его одежду и вещи дезинфицировали в карантинах, важно чтобы их проверили в ближайшем губернском городе или здесь, а затем опечатали. "Подорожную", или "дорожный пропуск", или "требование на предоставление лошадей", надо так же брать здесь на весь свой путь, тянущийся через русские владения. В нашем случае это был путь от Моздока до Лемберга, за который мы сразу заплатили по 2 копейки (в бумажных деньгах) за версту для каждой лошади. За 1902 версты мы заплатили 152 рубля 20 копеек» [7, р. 250]. По самому же Кавказу англичане, как и все другие путешественники, передвигались «с оказией» - под охраной российских солдат и казаков, и первый промежуток дороги от Тифлиса до Моздока, был оплачен отдельно как находящийся «вне российской короны» и не подпадающий под правила передвижения для внутренних территорий Российской империи.

«В Воскресенье, 13 Июля, транспорт выехал из Тифлиса в Моздок под прикрытием охраны. За ним последовали и мы, после обеда у генерала Кутузова, который, как я полагаю из вежливости, ... проводил нас с дополнительной охраной под командованием офицера. В три часа мы покинули его верхом, отослав заранее свой багаж на четырех почтовых лошадях, за которых мы заплатили по две копейки серебром за версту пути помимо того, что было уплачено за пользование имперской почтовой службой» [7, р. 251]. По дороге из Тифлиса англичане любовались руинами Мцхета [7, p. 251] и пересказывали услышанные ими истории о хищничестве лезгин - «храброго племени, о котором говорят, что они презирают утонченность и роскошь в домашней жизни, считают недостойным спорное удовольствие пить вино и крепкие напитки, и освобождены теми же наивными обольщениями, что и большинство других детей природы» [7, р. 249].

Побывав в Грузии, англичане так же анализировали действия Российской администрации на Кавказе. В целом они считали их перекликавшимися с тем, чем занимались другие европейские страны на окраинах Мира. «Взгляды России на будущее этой страны [Закавказья], направлены на превращение региона в ворота для европейских товаров - в рынок для всех окружающих ее стран, а особенно, для снабжения товарами Персии и Турции. ... Главное препятствие для осуществления этого плана лежит в текущей обстановке и главное - в наличии многочисленных местных племен, неподчиняющихся никаким законам. ... Огражденные горами Кавказа, они ... и в настоящее время столь же свободны от закона и воинственны какими были и их предки двадцать веков назад, во времена Римской империи» [7, p. 248-250].

Россия, с точки зрения Джонсона, имела такое же право вести колонизацию Кавказа, как и Британия Индию. Более того, английский офицер давал имперским властям чисто практические советы для укрепления своих позиций: «Первое, что может сделать Россия - это постараться взять под свой контроль столько Персидских и Турецких территорий, сколько позволят международные трактаты. Следующим шагом должно стать утверждение среди большей части черкесского населения вероучения Греческой церкви в том виде, в каком она присутствует в Армении и Грузии. И если, делая это, русские откроют бесплатные семинарии для подготовки служителей, то они со временем смогут побудить и черкесов посылать в них своих детей для обучения чтению и письму, научив их воспринимать христиан как друзей, а не непримиримых врагов...) [7, р. 248250]. Приведенные оценки, на наш взгляд, пересказывали то мнение, которое путешественники услышали в Тифлисе от русских военных. Именно так - развивая инфраструктуру Грузии, инкорпорируя в административный аппарат и армию местные элиты и сочетая развитие образования с христианским миссионерством, призывал действовать российские власти в начале XIX в. еще П. Д. Цицианов [2, с. 22-23.].

Путешественники так же позитивно отзывались об усилиях российского Кавказского корпуса по благоустройству региона, повторяя оценки имперских генералов. Русские солдаты, - пишет Д. Джонсон, заняты на Кавказе строительством и благоустройством тех мест, где они размещены. Эти работы позитивно воспринимаются самими солдатами, так как дают им какое-то разнообразие в военной службе. Местное же население, благодаря позитивным изменениям воспринимает русскую армию не как оккупационную, а как созидательную силу. Англичанин пишет, что подобное «единство военного и гражданского характеров было присуще лучшим временам Римской империи» [7, р. 256], повторяя бытовавшие в Кавказской армии сравнение - сам А. П. Ермолов образно называл Кавказские части «десятым римским легионом» [5, с. 12]. По словам же английских путешественников, военная колонизация Кавказа была необычайно выгодна и властям, ведь «имея скудное содержание, русские солдаты чувствуют себя вполне довольными, бодрыми и готовыми к ревностному общественному труду. Все они - ремесленники в том или ином смысле и как только батальон размещается на месте, он возводит 
для себя поселение из блокгаузов и обеспечивает себя практически всеми простыми продуктами, которые ему необходимы» [7, р. 257].

Как и все путешественники, следовавшие по Военно-грузинской дороге, англичане восхищались дикой красотой Дарьяльского ущелья, оставив его красочные описания. «Дорога вперед пролегает внутри очень узкого разлома вблизи Терека, стены которого, состоящие из скалистых пород, взмывают на огромную высоту. ... Напротив поста, который выстроен хорошо и имеет все необходимое для встречи путешественников, слева по Тереку стоит одинокая гора, на которой видны руины древнего укрепления. ... Глубокие ущелья прорезают даже самые высокие склоны, на которых растут ели, а обломки скал у их подножья иногда достигают 800 ярдов в периметре, обнажая поверхность крупнозернистого гранита, песчаника или сланца. И во всю длину этого природного барьера, сдерживающего Терек, проходит дорога, проведенная невероятным трудом. Ее проложили отчасти с помощью пороха, отчасти расчистили напряженными человеческими усилиями, получив в конечном итоге на голой скале нишу с плоской поверхностью, достаточной ширины и высоты, чтобы по ней могла пройти колесная повозка. Вот по этой-то дороге-коридору, где из голого камня состоят и пол, и стены, и потолок, а с его открытой стороны нет никакого ограждения, мы и последовали, почти оглушенные громовым ревом реки в провале внизу, причем от силы этого звука, казалось, вибрировали и дрожали даже камни вокруг нас. Удары вспененного потока в его узкое каменное дно и напор сжатой в теснине массы воды на запирающие ее ограды берегов, производят звук такой же тональности и мощи, как тот, что получается от столкновения двух встречных течений в узком морском проливе. Здесь же звук еще большей чистоты и мощи из-за того, что он рожден в глубине ущелья и поднимаясь из него, многократно отражается от нависающих со всех сторон гор, которые как будто сами стараются перекричать поток» [7, p. 257-258]. В данной записи интересно не столько романтичная зарисовка природы горного Кавказа, сколько восхищение автора теми людьми - русскими солдатами, которые смогли, проложить путь через скалы. Подобный взгляд на европейца, обуздывающего дикую природу на окраинах Мира, был очень характерен для колониального нарратива не только XIX, но и даже начала XX в. [8, p. 150].

Дикая горная цепь по оценке Джонсона стала домом для воинственных жителей. «Страну слева и справа от дороги населяют племена Осов или Осетин - очень отважного, вспыльчивого и несговорчивого народа. Их обычаи сильно отличаются от нравов грузинских крестьян, которых мы встречали во время наших предыдущих переходов» [7, р. 255], - пишет Джонсон. В записках англичанина мы не увидим попыток разобраться в характере местных жителей, или в движущих силах разраставшегося на Кавказе военного противостояния. Как и многие русские авторы того времени, Джонсон видел только одну сторону жизни Кавказских народов - их набеговую экономику, а необходимостью бороться с ней объяснял столкновения русских с горцами. «Необузданные осетины, которые проживают в окрестностях Владикавказа, - продолжает он, - часто лежат в засаде, поджидая путников, которых захватывают и держат в плену, до тех пор, пока не получат от русских выкуп. ... Мне показали наиболее опасные участки пути - узкие ущелья слева, ведущие в глубину гор, а также - глубокие долины, справа от Терека, покрытые лесом. В обеих частях местность от природы труднопроходимая и для того чтобы наказать грабителей, потребовалась бь большая группировка легкой пехоты, прошедшей специальную подготовку" [7, р. 261].

Владикавказское укрепление оставило позитивные впечатления в дневнике путешественника. «Небольшой городок Владикавказ, - пишет он, - построен на плоском дне глубокого черного ущелья, которое при каждом значительном дожде превращается в глубокую грязь. Дома выстроены из бревен и досок, покрыты соломой или пластами коры, круглые срезы которой раскрыты и выровнены для этих целей. Несмотря на свою скромную конструкцию, дома выглядят очень опрятно, стены добела отмыты, а рамы дверей и окон выкрашены другими цветами. Окна очень малы, но застеклены. ... Так строят дома в деревнях всего русского франтира - как представляется с большим и ненужным перерасходом строительного леса, хотя этот материал имеется здесь в таком количестве, что его предпочитают, как требующий наименьших затрат труда по сравнению со всеми другими» [7, р. 262].

Как пишут англичане, во Владикавказе процветал целый бизнес по прокату транспорта, причем путешественникам удалось нанять две телеги для перевозки своих вещей по цене, ниже установленной на официальных почтовых станциях. Однако, сам путь по Кавказской Линии был возможен только под охраной солдат и за обеспечение этой охраны с путешественников взяли дополнительную плату. «Возможности, которые предоставляет подобный эскорт в высшей степени удобны для тех, кто может путешествовать с хорошей скоростью, - пишет Д. Джонсон. - ... Дороги на Кавказе в целом в хорошем состоянии и доступны даже для колесного транспорта. Здесь есть только один горный хребет, через который надо перебираться, но проход без сомнения столь же трудный, как Гаты в Индии. ... В целом, средства, предоставляемые русским командованием настолько объемны, а издержки путешественника столь умеренны, что путешествие по Кавказу не должно считаться неосуществимым мероприятием. Более того, невероятное великолепие пейзажей, красота и разнообразие ландшафтов, необычность манер, одежды и обычаев людей, с которыми встречаешься по дороге, все это вместе очаровывает взгляд путешественника настолько, что и усталость делается несущественной» [7, р. 263-264].

Англичане обращали внимание не только на природу, но и на людей, живших на Кавказе. Они 
отметили привычку жителей «носить оружие, как только они выйдут из дома» [7, р. 264], причем вооружены даже дети 8-10 лет. Малолетние, как пишет Джонсон, носили луки и стрелы, а кто постарше - имел уже огнестрельное оружие.

Особое внимание путешественники обратили на кавказскую одежду - знаменитые бурки с газырями. «Лацканы карманов верхней одежды у них укорочены и вдоль всей груди пристегнуты, или пришиты ряды гильз для патронов» [7, p. 265]. Знакомым лишь с европейской тактикой ведения боя, английским офицерам казалось дикостью хранить патроны не в сумке, а в газырях бурки - вблизи от замка кремневого ружья, что, по их оценке, подвергало стрелка явной опасности. Ведь если произойдет осечка и вылетевшая искра случайно попадет в газыри, то солдат получит травму от своего же оружия [7, р. 265], - считал Джонсон. Англичане, конечно, не имели представления о том, что на Кавказе никто не воюет в сомкнутом строю, а казаки и солдаты стремились использовать не европейские приемы боя а перенимать тактику, оружие и одежду своего противника.

Романтические зарисовки о природе и жителях Кавказа в дневнике заканчивались временем пребывания англичан в его горной части. Заметки - Степном Предкавказье отражают прямо противоположные эмоции. Так, уже выехав из Владикавказа «с оказией», англичане испытали на себе всю скуку медленного передвижения по степи. Их впечатления от конвоя были точно такими же, как и у всех русских путешественников. «День был жаркий, а путь, который мы проделали на почтовых лошадях, оказался невероятно скучным изза медленного продвижения пехоты и пушки» [7, p. 267], - пишет Джонсон о дороге к Екатериноградской станице.

В Моздоке, который, по словам Джонсона "уже считается внутренней Россией» начиналась почтовая служба, которая предоставляла путешественникам возможность ночевать на почтовых станциях и менять лошадей. Однако, мирная жизнь в регионе еще только налаживалась «В этой очень отдаленной части Российской империи путешественник не найдет ни персидских караван-сараев, ни нормальных постоялых дворов. Там же где нет и хороших почтовых станций, почтальон обычно ждет в полицейском участке пока не появится путник. Этот человек по требованию предоставляет свои услуги - что-то вроде квартирования в частном доме; семья которая это делает, за разумную плату предоставляет или готовит еду: птицу, яйца, рыбу или молоко, хлеб и масло» [7, р. 271]

Главное удобство, которое получили англичане благодаря использованию почтовой службы это возможность продолжить свой путь в крытой повозке - «кибитке», конструкцию которой Джон$\mathrm{COH}$ тщательно описал в своем дневнике. «Кибитка напоминала половинку бочонка гигантских размеров - 6 на 4 фута, распиленного в длину и поставленного на колеса» [7, р. 271]. Корпус стягивался железными полосами, но вся ходовая часть была деревянной. Первоначально англичане не придали этому значения, с юмором описывая вызвавшую их смех деталь в конструкции кибитки - деревянный ящик, приделанный сзади, в который сложили вещи. Металлические предметы багажа бились друг о друга и громыхали на каждой кочке, придавая особый колорит пути по степной дороге [7, р. 271-272]. Проделав в своем транспорте путь до Георгиевска, англичане перестали смеяться и отмечали, что в безрессорной кибитке «трясет так, что несмотря на то, что мы проехали всего 114 верст по очень мягкой дороге, мы набили себе синяки даже на плечах» [7, р. 276]

Вскоре выяснилось, что кроме бытовых неудобств, на которые на Кавказе никто не обращал внимания, гораздо большее беспокойство путешественникам доставляли другие особенности конструкции их транспорта - деревянные колеса и оси, которые за время пути от Моздока до Новочеркасска ломались четыре раза. Кроме того, после очередной поломки в селе Преградном, Джонсон с досадой отмечает, что если оси постоянно не смазывать толстым слоем свиного сала то они от трения начинают дымиться и «ловить огонь» $[7$, р. 283].

Русские села и казачьи станицы по дороге из Моздока были довольно детально описаны в дневнике. «Мы прибыли в Павлодольскую большое село с опрятными лачугами, побеленными снаружи» [7, р. 273], - пишет англичанин. В нем, по словам Джонса, жили жители, носившие одежду, «напоминающую коренных португальцев в Индии» [7, р. 273], но многие имели «плоские лица Калмыцких татар» $[7$, р. 273]. Жизнь в поселке бьет ключом: «дети, лошади, свиньи, птица и всякая живность бегают по станице вперемешку» $[7$, p. 273], - писал он.

Незнакомый с историей колонизации Степного Предкавказья, автор не видел существенной разницы между казачьими станицами и бывшими укреплениями Азово-Моздокской линии. Так, в Екатеринограде, который Джонсон считал лишь селом средних размеров, он отметил наличие церкви и следов каких-то укреплений, а в бывшей Павловской крепости, не заметил вообще ничего достойного внимания. Гораздо больше англичан в этом поселке волновала первая поломка их транспорта - колесо, соскочившее с оси [7, р. 274]

В главном административном центре Кавказской губернии - Георгиевске, путешественники заметили новые черты: «Георгиевск уже явный город, в котором много хороших казарм и квартир для солдат, - пишет Джонсон. - Здесь находится резиденция генерала дель-Поццо - Командующего войсками в Кабарде и на Кубани; он так же губернатор той провинции, границы которой простираются к Дону. В это время он отправился с 6 тыс. человек устраивать пост на реке в земле чеченцев» [7, р. 275], - отметил путешественник.

Из Георгиевска англичане двинулись на Север через крестьянские деревни: Александрию и Саблинскую, а также через бывшие укрепления Азово-Моздокской Линии - крепости Александровскую и Северную. Дорога до Северной заняла у англичан 8 часов 14 минут и помимо скру- 
пулезного подсчета времени, вызвала лишь одно замечание: «Мы нашли дорогу необычайно жаркой и пыльной. Для путешествия по ней годится одежда исключительно синего или серого цветов; белье любого другого, особенно белого, через час становится таким грязным, что в нем стыдно ходить» [7, p. 279]. Бывшая крепость Северная в начале XIX в. утратила свое военно-стратегическое значение и превратилась в бедное село. Оно было отмечено в дневнике не описанием каких-либо достопримечательностей, а сожалением, что во всем поселке никто не смог разменять англичанам 5 рублевую денежную купюру и сдачу пришлось записать в подорожную в счет будущего пути [7, р. 281]

На следующий день путешественники достигли губернского города Ставрополя, в котором «нельзя было найти ни сменных лошадей, ни места для отдыха и только личный приказ губернатора помог исправить дело. Мы поместились в доме какого-то купца, а на следующее утро через начальника полиции добыли двух лошадей из тех трех единственных, что остались на почте» [7, р. 280]. Интересно, что отсутствие в городе условий, облегчающих жизнь частным путешественникам, Джонсон объясняет растущим значением центра управления Кавказом. По его наблюдениям, через Ставрополь проходили коммуникации, и офицеры разного ранга отвлекали на свои нужды имевшиеся в городе почтовые ресурсы [7, p. 280]; англичане так же заметили необычайно большой поток транспорта, везущего из Ставрополя припасы и амуницию на Юг - для войск, расположенных в Моздоке и Грузии [7, р. 281]. «Там так же располагалось четыре или пять сотен рекрутов, что явно указывает на то, что делаются приготовления для усиления войск в Грузии. Офрицеров побуждают быстрее ехать к их полкам, а нас непрестанно расспрашивали о Персии, русском посольстве в ней, Индии и других интересующих их предметах» [7, р. 281].

О самом городе англичане отзывались как о стремительно растущем центре: «Ставрополь город довольно больших размеров, выглядит расцветающим. Горожане расширили свою церковь и покрывают ее крышу медью. Улицы здесь прямые и дома стоят на расстоянии друг от друга, что предотвращает распространение как инфекции, так и огня. Ограды, однако, деревянные, сбитые из высушенных деревянных планок. Крыши домов - из соломы, но они, похоже, не боятся огня, так как постоянно влажны и забиты пылью, а также проконопачены дерном, благодаря чему, на них растет трава и сорняки. Все крыши выглядят именно так, а их скаты довольно крутые» [7, р. 281].

Покинув Ставрополь на следующий день, путешественники отправились на Север по Черкасскому тракту через бывшие укрепления, а теперь - села Московское и Донское. Они не заметили здесь каких-либо следов фортификационных сооружений, и будучи незнакомыми с административной картой региона, даже считали, что Донское - «франтирное поселение Донского округа, находящееся под юрисдикцией Гетмана Платова» [7, р. 282]. Путешественники отмечали степной характер ландшафта, заметили общее стремление крестьян строить поселения вдоль рек и сокрушались об отсутствии деревьев «даже вблизи деревень»[7, р. 282].

Англичане отметили явный мирный характер колонизации Степного Предкавказья: по нему уже можно было двигаться без конвоя, а в селах встречалось много женщин и детей. Вместе со следами мирной жизни во всех встречных деревнях была видна явная бытовая неустроенность. Последняя очень раздражала англичан. «Дома и жилища забиты поросятами, курами, птицей, кошками и собаками; блохи и мухи в таком количестве, что иногда от них чернеет пол, стены и балки. В углах всех жилищ помещаются медные плошки с грубо намалеванными (daubs) рисунками святых и Богородицы. Люди побогаче вешают лубки религиозной тематики, вперемешку с портретами старших офицеров, царей и выдающихся деятелей - все они предстают верхом на лошадях, - известный и действенный метод пропаганды военного духа и вызова чувства подражания среди низших слоев общества» [7, р. 282].

Однако, еще большие неудобства ждали путешественников на официальной административной границе Кавказской губернии и Донской Области, в селении Средне-Егорлыкском, где был расположен очередной карантин. В своих записках Д. Джонсон оставил описание прохождения досмотра и “очистки» вещей - процедуры, требовавшейся для всех лиц, въезжавших в Центральную Россию. Багаж путешественников был подвергнут процессу окуривания в отдельном помещении; все металлические предметы, включая монеты, часы, оружие, инструменты, а так же образцы минералов которые англичане везли с собой, протерли уксусом; их бумаги и документы разложили на деревянной решетке и подвергли специальной обработке газом, выделявшимся при химической реакции, а даже на лекарственных порошках заменили их бумажные обертки. «Ни одна вещь не избегла этой участи» [7, р. 285], пишет Джонсон

После очистки, путешественников разместили в карантинном бараке, причем, привычные к комфорту англичане с негодованием описывают условия, которые им предоставила карантинная служба. «Хибара (the hovel) в которую нас водворили и где мы для верности должны были провести семь дней, была опущена на 3 с половиной фута под землю, что составляло ровно половину ее высоты. Небольшие отверстия окон расположенные на уровне земли почти наглухо заросли травой и сорняками, которые росли вокруг всего жилища, достигая высоты его крыши. ... Когда же мы зашли внутрь, то обнаружили, что жилище кишит блохами, комарами и мышами. Стены и балки были буквально черны от мух, которые садились на любую вещь, которую мы выпускали из рук хоть на минуту. Внутри были прибиты дощатые лежанки, на которые мы постелили свои постели, но так как мы не позаботились прихватить с собой ни простыней, ни покрывал, то не смогли спать ночью. ... Во время нашего прибытия, здесь нельзя было найти хоть немного провизии кроме 
дурной баранины, кусок которой был зажарен на огне, разведенном на сырых дровах, и ломтя очень плохого черствого черного хлеба, который нам дали чтобы ее заесть»[7, р. 286].

Во время тоскливого ожидания завершения карантинного срока, Джонсон приглядывался к системе работы всего заведения, которая вызывала у него острую критику. «... Всех путешественников из Грузии и других мест, - писал он, заставляют проходить карантин вместе с теми, кто прибыл из Кабарды и Черкессии, где, как известно, чума гуляет постоянно. А, между тем, людям оттуда разрешено приносить с собой даже меховую и шерстяную одежду, и, кроме того, сотни и тысячи шкурок овец, коз, зайцев, лис и т.п. в ожидании очистки вывалены под навесом на открытом воздухе в непосредственной близости от того места, где вынуждены слоняться люди, живущие в карантине. Даже преступники в кандалах содержатся вместе со всеми и спят с ними под одной крышей. И становится очевидным тот факт, что несмотря на то, что, если бы мы не прошли карантин, то проехали бы через всю Россию, не принеся с собой чумы, мы здесь были подвергнуты высочайшему риску подхватить инорекцию и перенести ее дальше из этого места» [7, р. 288289]. Замечания Джонсона, конечно, объяснимы его раздражением от условий жизни, однако его опасения не подтверждались записками других путешественников XIX В., да и сам комендант карантина заверил англичанина, что чумы в Среднем Егорлыке не видели уже 8 лет [7, р. 289].

Проведя на территории карантина установленные 7 контрольных дней, англичане смогли продолжить путь по России, навсегда покинув Кавказ. Они проехали через Донскую область, Новороссию и Польшу, затем через земли Прус- сии и попали в Голландию, откуда благополучно переправились в Англию. «Подводя итог, следует отметить, что время, затраченное на поездку, составило около семи месяцев, а сумма - около 220 фунтов, вместо рассчитывавшихся ранее 378 " [7, p. 376], - отмечает Джонсон, давая в конце записок своим соотечественникам ряд практических советов о том, как лучше устроить свой быт, если кто-то из них решится, как и автор, проделать сухопутный переход в Индию.

Таким образом, яркий источник, который представляют собой записки путешественника, позволяет взглянуть как на Кавказ в целом, так и на историю освоения региона в составе Российской империи с точки зрения людей, живших в первой половине XIX в., попытаться вникнуть в сущность тех проблем, с которыми они сталкивались в повседневной жизни. Путешественники, такие, как Д. Джонсон, конечно, были людьми своего времени и судили о непривычных им вещах с позиций политико-культурного опыта своей цивилизации. «Записи, которые о своих поездках оставили подобные исследователи, несут в себе основу, написанную в тональности, звучащей сейчас даже несколько оскорбительно - непреложную уверенность в собственном превосходстве, в том, что "белый человек знает лучше". Однако, невозможно, читая записи, не разделять восхищения их авторов перед ярким разнообразием незнакомых народов, животного и растительного мира, с которыми они встречались» [8, р. 109], - отмечает современный английский исследователь Джереми Паксман. Отечественному же историку, записки иностранцев дают богатый материал, который приобретает особый интерес при его сопоставлении с оценками отечественных авторов.

\section{Источники и литература}

1. Броневский В. Поездка на Кавказ. СПб.: [б.и.], 1834. 117 с.

2. Кавказ. Газета политическая и литературная. 1846. №6. С. 22-23.

3. Правила обозрения местности и целого края // Отдел письменных источников Российской национальной библиотеки (ОПИ РНБ). Ф.68. Оп.1. Д.49.

4. Розен Г. В. Кавказ, Индия и Средняя Азия // Государственный исторический музей (ГИМ). Ф.6. Д.66.

5. Служба Ширванца. 1726-1909. Б/М, Б/г. 148 с.

6. British Library: Printed Collections/Qatar National Library. ORW.1986. a.2833. URL: https://www.qdl.qa/en/archive/81055/ vdc_100033803785.0x000004 (Дата обращения: 14.05.2018).

$\overline{7}$. Johnson J. A Journey from India to England, through Persia, Georgia, Russia, Poland, and Prussia, in the year 1817. London: Printed by A Strahan, 1818. $376 \mathrm{p}$.

8. Paxman J. Empire. What Ruling the World Did to the British. London: Penguin Books, 2011. 335 p.

\section{References}

1. Bronevskiy V. Poezdka na Kavkaz. (The Travel to the Caucasus). St.Petersburg, 1834. 117 p. (In Russian).

2. Kavkaz. Gazeta politicheskaya i literaturnaya (Caucasus. The Newspaper of Political and Literature Content). 1846. No. 6. P. 22-23. (In Russian).

3. Pravila obozreniya mestnosti i celogo kraya (The Roles for Observations of Sites and the Whole Lands) // The Departament of Written Sources of Russian National Library. (OPI RNB). F.68. S.1. D.49. (In Russian).

4. Rozen G. V. Kavkaz, Indiya i Srednyaya Aziya (Caucasus and Middle Asia) // The State Historical Museum. (GIM). F.6. S.1. D.66. (In Russian).

5. Sluzhba SHirvanca. 1726-1909. (The Service of the Shirvan Regiment Member. 1726-1909) No Author, No publisher data. 148 p. (In Russian).

6. British Library: Printed Collections / Qatar National Library. ORW.1986. a.2833. URL: https://www.qdl.qa/en/ archive/81055/vdc_100033803785.0x000004 (Accessed: 14.05.2018).

7. Johnson J. A Journey from India to England, through Persia, Georgia, Russia, Poland, and Prussia, in the year 1817 London: Printed by A Strahan, 1818.376 p.

8. Paxman J. Empire. What Ruling the World Did to the British. London: Penguin Books, 2011. 335 p. 